\section{O traço do personalismo das instituições assistenciais: doadores, doações e projeção social no Ceará oitocentista}

\section{The trait of personalism in charitable institutions: donors, donations, and social projection in nineteenth- century Ceará}

\author{
Cláudia Freitas de Oliveira ${ }^{i}$ \\ i Professora, Departamento de História/ \\ Universidade Federal do Ceará. \\ Fortaleza - CE - Brasil. \\ orcid.org/0000-0001-7608-6179 \\ claudia.oliveira@ufc.br
}

Recebido em 28 fev. 2019.

Aprovado em 2 jul. 2019.
OLIVEIRA, Cláudia Freitas de. O traço do personalismo das instituições assistenciais: doadores, doações e projeção social no Ceará oitocentista. História, Ciências, Saúde - Manguinhos, Rio de Janeiro, v.26, supl., dez. 2019, p.129-145.

Resumo

No Brasil oitocentista evidenciou-se a emergência de instituições assistenciais. Por meio delas, os estados provinciais projetaram membros das elites políticas e econômicas nomeando-os grandes benfeitores. Homens de notoriedade local desempenharam papel na construção de determinados espaços asilares por meio de práticas que ratificaram seu prestígio social não apenas entre seus pares e para sua época, mas também para a memória e a história das instituições às quais estavam vinculadas. $\mathrm{O}$ artigo problematiza a construção de três instituições assistenciais no Ceará: Asilo de Mendicidade, Colônia Orfanológica Cristina e Asilo de Alienados São Vicente de Paula, cuja tônica discursiva e ações filantrópicas estavam inseridas no cenário da grande seca de 1877-1879.

Palavras-chave: instituições assistenciais; asilos; filantropia; Ceará oitocentista.

Abstract

In the nineteenth century, Brazil witnessed the emergence of the first welfare institutions. These became the platforms for provincial states to raise the status of their political and economic elite, naming them great benefactors. Men of local repute played active roles in building certain institutional spaces, employing practices that reinforced their social prestige not just among their peers and for their time, but also for the memory and history of the institutions with which they were involved. The building of three welfare institutions in the province of Ceará is problematized: Asilo de Mendicidade, Colônia Orfanológica Cristina, and Asilo de Alienados São Vicente de Paula, whose discourse and philanthropic actions were entangled with the great drought of 1877-1879.

Keywords: welfare institutions; asylums; philanthropy; nineteenth-century Ceará. 
$\mathrm{A}$ seca de 1877-1879 foi bastante difícil para o Ceará: milhares de vidas ceifadas, quadros epidêmicos alarmantes, economia devastada. Uma ampla literatura memorialista e historiográfica registrou a dimensão do flagelo em suas cores e tintas fortes sobre o caos social pelo qual passava a província (Neves, 2000; Chaves, 1995; Theófilo, 1997, 1922). O início dos anos 1880, entretanto, anunciava-se como promessa de reerguimentos social e econômico. Passado o flagelo, era necessário promover medidas estatais e assistenciais com o propósito de findar suas nefastas consequências ainda presentes no cotidiano da população, sobretudo da capital, Fortaleza.

Nos anos 1880 foram produzidos discursos provinciais acerca da construção de três instituições asilares, voltadas para públicos específicos, mas inseridas em preocupações semelhantes e que atenderam às mesmas expectativas das elites políticas e econômicas.

O artigo aborda o processo de concepção de três espaços assistenciais, o Asilo de Mendicidade, a Colônia Orfanológica Cristina e o Asilo de Alienados São Vicente de Paula, e estabelece articulações entre si como proposta de construção de um projeto societário para Fortaleza em que se evidenciavam discursos e ações filantrópicas intrinsicamente voltados para as práticas de controle e disciplinamento sociais.

A proposta das autoridades públicas de Fortaleza de oferecer abrigo para três segmentos de indesejáveis socialmente - mendigos, órfãos e loucos - esteve inserida em um cenário de evidentes ameaças e perturbação à ordem pública. Motivadas pelo aumento da mendicância, delinquência e doenças mentais, as elites de Fortaleza expuseram sua preocupação com as crescentes mazelas sociais presenciadas nas ruas da capital e sustentaram seus discursos filantrópicos, sobretudo a partir de enunciados caritativos e normativos.

Com esse intuito, elaborou-se uma vasta e consoante produção discursiva na qual o sentido da filantropia deu o tom justificativo para a necessidade da criação das instituições atendidas sob a mesma perspectiva, ou seja, oferecer abrigo aos ditos desvalidos da seca.

\section{0 asilo de mendicidade}

Desde o primeiro ano de seca, o governo provincial demonstrava intenção de construir um asilo destinado ao recolhimento de mendigos devido ao aumento significativo destes pelas ruas da cidade. Os jornais locais noticiavam as intenções do governo de execução da obra, acentuando as tintas partidárias, fosse para exaltar o presidente da província, fosse para criticá-lo. Em junho de 1877, o jornal oposicionista O Retirante, apesar de reconhecer a necessidade da criação da instituição asilar, ironizava outro jornal, o conservador Constituição, ao afirmar que o governo estava muito "caridoso e até já prega sermões de lágrimas" (O Retirante, 15 jun. 1877).

Paralelamente às disputas político-partidárias que se intensificavam com o agravamento da seca, em julho do mesmo ano, o presidente da província nomeou uma comissão para arrecadar donativos para a obra (Theófilo, 1922, p.105), e, no dia 2 de dezembro, a pedra fundamental foi lançada.

Durante o processo de construção do asilo de mendicidade, a iniciativa da obra foi atribuída pelos contemporâneos a uma única pessoa, o ex-vice-provedor da Santa Casa de Misericórdia de Fortaleza, o senhor Joaquim da Cunha Freire, também conhecido como 
barão de Ibiapaba que, em gesto "grandioso", noticiado oficialmente pelo então presidente da província, José Júlio de Albuquerque Barros, doou não apenas a quantia expressiva de 10:000\$000 réis, como o terreno para a fundação do edifício.

A partir de seu feito, Joaquim da Cunha Freire passaria, então, a fazer parte de discursos, tanto para a época como para a posteridade, na qualidade de grande idealizador do asilo de mendicidade. Discursos memorialistas foram produzidos, como o do literato contemporâneo Antônio Sales, em Novos retratos e lembranças, com o objetivo de homenageá-lo. Na obra, o autor relatou breve "histórico" de sua vida, afirmando que o barão de Ibiapaba fez fortuna com o comércio de algodão e com a construção da Casa Severiano Ribeiro da Cunha \& Irmão, considerada a "mais importante do Estado". Referindo-o como "multimilionário", o autor afirmou que Joaquim da Cunha Freire possuía prestígio entre a facção político-partidária conservadora denominada "graúda" e destacou-o por ter sido várias vezes vice-presidente da província e ter assumido interinamente a presidência em 1874 (Sales, 1995, p.36).

Outro autor que projetou a importância social de Joaquim da Cunha Freire foi o historiador Francisco Lima, ao considerá-lo um dos nomes mais atuantes na fundação da via férrea de Baturité na província, como dirigente de "empresa privada" no período correspondente a 1870-1876 (Lima, Pereira, 2007, p.185).

Joaquim da Cunha Freire foi exitoso em sua trajetória política, construída paralelamente ao enriquecimento pessoal. Segundo o Arquivo nobiliárquico brasileiro:

Dedicando-se à carreira comercial, soube acumular avultada fortuna. Foi chefe político de grande influência, foi Coronel da Guarda Nacional, Presidente da Câmara Municipal de Fortaleza e da Junta Comercial, da Caixa Económica e Monte de Socorro da Província (Vasconcellos, Smith de Vasconcellos, 1918, p.182).

Sua distinção social iniciou-se com o título de comendador pela Imperial Ordem da Rosa e consagrou-se com o de barão em 1874. O bom trânsito na política nacional evidenciou-se sobretudo a partir da década de 1870 e manteve-se até o final do Império, quando o governo central lhe autorizou concessões para exploração de riquezas minerais como chumbo, entre outros metais, na província do Ceará.

Datou de 1873 o primeiro decreto autorizando Joaquim Freire à exploração de minérios no município de Acaracusinho por um período de três anos. Em 1888, dois novos decretos foram publicados estendendo a exploração de chumbo aos municípios de Viçosa e Ipu. Sobre os decretos dos anos 1880, torna-se importante destacar que o título de barão de Ibiapaba - concedido um ano após a publicação do primeiro decreto - passou a substituir o nome do solicitante no caput, demonstrando significativo diferencial no tratamento da nova condição social do beneficiário. A omissão do nome de batismo, entretanto, estava longe de representar, ou simplesmente alimentar, uma vaidade pessoal; ela, na prática, respaldava maior poder para exploração econômica provincial por parte de Joaquim Freire. Nos decretos de 1888, além de o barão obter autorização para explorar minérios em dois municípios, Viçosa e Ipu, a área estendia-se a "um milhão de metros quadrados $\left(1.000 .000 \mathrm{~m}^{2}\right)$, cada" (Brasil, 1888). Essa situação, bastante favorável ao ilustre solicitante, alterou-se, contudo, com o fim do Império. O último decreto de concessão de benefício 
para exploração de minério no município de São Benedito foi registrado em maio de 1889, mas com o prazo reduzido de apenas seis meses.

Voltando à década de 1870, no segundo ano da seca, em 1878, a obra do asilo de mendicidade, situada no Outeiro da Prainha, foi anunciada pelos órgãos públicos e imprensa como estando "em fase bastante adiantada", resultado da não interrupção dos trabalhos desde seu início. O então presidente da província, João José Ferreira de Aguiar, em relatório de 22 de fevereiro, demonstrava confiança na execução rápida da obra ao reafirmar a existência de recursos. Para o memorialista Rodolfo Theófilo (1922, p.135), a obra fora proveniente tanto da ação filantrópica dos particulares sob a forma de donativos como da ação governamental, advinda de socorros públicos.

O jornal liberal $O$ Cearense também defendeu a necessidade de finalização da obra do asilo de mendicidade. Entretanto, não era, inicialmente, o sentimento de piedade em relação ao desvalido o motivo destacado na matéria. Segundo a historiadora Josinete Souza (1999, p.37), o discurso da imprensa voltava-se contra as ações praticadas por "esmoleres" que proliferavam em abundância pela cidade e atentavam contra os bons costumes. Seus atos eram considerados "imorais e repugnantes", e o jornal salientava que nem sempre os que pediam esmolas eram realmente mendigos. Assim, a intenção em torno da construção do asilo para a mendicidade era percebida para além do sentido filantrópico, posto que colocaria fim a "essa nojenta especulação", quer dizer, ao ato indiscriminado de pedir esmolas.

Se, por um lado, o conteúdo da matéria do jornal evidenciava o elemento disciplinador em torno da construção da instituição assistencial asilar, convém destacar, por outro, que a ideia da filantropia se manteve presente. O Cearense reforçava o lugar da filantropia praticado por particulares na condução de obras públicas ao afirmar que o asilo "envolve a caridade no manto da esperança e afasta da esmola os verdadeiros necessitados" (Souza, 1999, p.37). Isto é, para o jornal, por meio da construção do asilo de mendicidade seria possível distinguir os verdadeiros dos falsos mendigos que, tendo estes condição de trabalhar, aproveitavamse da situação de penúria da cidade para conseguir filantropia, sem, contudo, a merecer.

A prática dos maltrapilhos de perambular pela cidade incomodava os moradores, infringia os códigos de postura e causava desconforto para as elites que observavam ações violáveis às boas maneiras de convivência. Mesmo em época extraordinária como a da seca, os códigos de postura existiam e eram inequívocos em seus artigos. Era vedada aos indivíduos uma série de ações, tais como: promover disputas em controvérsias nas ruas, praticar atos obscenos, "andar pelas ruas indecentemente vestido, deixando de trazer, pelo menos, camisa e calça, sendo aquela por dentro desta", entre outras que pareciam ser completamente descabidas de ser obedecidas em um ambiente onde grande quantitativo de pessoas promovia distintos delitos e andava quase seminu pelas ruas da cidade.

Era difícil controlar os variados "espetáculos" promovidos por mendigos que atentavam contra a civilidade, daí a justificativa de seu recolhimento em abrigo próprio. O número de pedintes crescia tão assustadoramente, segundo Rodolfo Theófilo, que o sábado fora instituído como o dia das esmolas. Para o literato e memorialista, algumas categorias de trabalhadores, como as lavadeiras, deixavam de trabalhar nesse dia para ir de porta em porta pedir ajuda: 
Hoje, nos dias de sábado, vê-se uma procissão de esmoleres, rua abaixo e rua acima, e tão crescida que espanta. A falta de brio da arraia miúda em Fortaleza, chegou a ponto de santificarem o sábado. Reservam este dia para as esmolas. Já me haviam dito isto, que achei extravagante, mas depois verifiquei ser verdade.

As lavadeiras, por exemplo, não trabalham nos sábados, pedem esmolas ... e todas as vezes que por eles passei no mencionado dia não vi uma lavadeira sequer (Theófilo, 1997, p.117).

O projeto de construção da instituição assistencial asilar visava oferecer resposta a uma situação de mendicidade tida como desordenada em Fortaleza. Contudo, apesar dos discursos convergentes a seu favor e de o prédio encontrar-se em fase adiantada e concluída em 1880, ele não foi utilizado para os fins originalmente propostos. Somente no início do século $\mathrm{XX}$, foi inaugurado um asilo para mendigos na cidade, mas constituído por novos atores e grupos sociais à frente, em destaque, a maçonaria (Silva, 2009, p.270). O que permaneceu, entretanto, nos discursos produzidos tanto no século XIX como no início do $\mathrm{XX}$ foram os valores em torno das noções de filantropia e civilização quanto ao tratamento dado à matéria da mendicidade.

Também envolta no sentido da filantropia, outra instituição assistencial foi planejada em fins da década de 1870, a Colônia Orfanológica Cristina.

\section{Colônia Orfanológica Cristina}

Segundo o historiador Guilherme Studart (1896, p.27), a Colônia Orfanológica Cristina, visava receber, gratuitamente, meninos e meninas entre 7 e 12 anos, nomeados "órfãos e ingênuos cearenses desvalidos" para oferecer-lhes "abrigo, educação e amparo". A seca foi novamente considerada pelas autoridades públicas fator decisivo para a concretização da obra. De acordo com a lei provincial n.1.876 de 11 de novembro de 1879, tornava-se "urgente oferecer asilo e conveniente educação aos órfãos que as calamidades da seca e da peste grassaram nesta província durante três anos" (p.274).

De forma semelhante ao processo de construção da instituição assistencial voltada para a mendicidade, membros das elites provinciais destacaram o mérito da construção da Colônia Orfanológica ao comendador Luiz Ribeiro da Cunha, rico comerciante que, em 1871, controlava a navegação costeira provincial por meio de serviços de cabotagem a vapor (Rodrigues, 2018, p.77). Em 1880, Luiz Ribeiro da Cunha doou cerca de quatro léguas quadradas de terras em Canafístula e, como recompensa pelos relevantes "serviços prestados à nação", o meritoso cidadão foi condecorado com o título da Ordem da Rosa pelo governo imperial. Considerado por Guilherme Studart pessoa humilde de nascimento, natural de Portugal, mas "cearense de coração", o comendador fez "carreira comercial e construiu grande fortuna" (Studart, 1922, p.384).

A doação de Luiz Ribeiro da Cunha também foi referida pelos órgãos políticoadministrativos em discurso proferido na assembleia provincial pelo então presidente da província, José Júlio de Albuquerque Barros, ao ressaltar que, além do terreno, Luiz Ribeiro da Cunha também havia doado todos os gados existentes na fazenda. 
As terras doadas localizavam-se em Canafístula, no município de Acarape, a 45km de Fortaleza, onde se localizava uma das estações da estrada de ferro de Baturité. O terreno foi avaliado positivamente em sua qualidade e vastidão por possuir uma série de vantagens, como: "compreendendo serras e extensas planícies, a riqueza das matas, as benfeitorias já existentes, entre as quais algumas casas, cercados e plantações" (Fala..., 1 jul. 1880, p.44). Essas qualidades foram, "além da facilidade dos transportes" (p.44), as razões apontadas pelo presidente da província para a escolha do local para a edificação da Colônia Christina, onde também deveria ser construída uma capela.

Instituições voltadas para a infância pobre já haviam sido erguidas anteriormente em Fortaleza. Uma das mais antigas foi o Asilo de Educando Artífices, inaugurado na década de 1850, mas com vida efêmera. Anos depois, em 1865, no mesmo prédio fundou-se o Colégio da Imaculada Conceição, destinado à educação, instrução moral e intelectual de meninas e moças, ricas e pobres. Praticamente, esse foi o único estabelecimento assistencial existente na cidade destinado à orfandade pobre, antes do advento da seca. Entretanto, durante o flagelo, "aumentou extraordinariamente o número de infelizes órfãos" (Fala..., 1 nov. 1878, p.34) em Fortaleza, o que ocasionou, inicialmente, o aumento também do montante de verbas destinadas ao Colégio Imaculada Conceição. Contudo, como esse espaço não comportava toda a demanda, a construção de nova instituição assistencial tornou-se questão urgente nos discursos proferidos pelas autoridades e elites provinciais.

A Colônia Orfanológica Christina foi inspirada na Colônia Agrícola Isabel, fundada em 1874, na província de Pernambuco e voltada para meninos negros, índios e brancos (Arantes, 2005). A proposta da colônia do Ceará visava oferecer ocupação útil aos órfãos da seca, por meio da promoção do ensino profissional e do incentivo aos plantios de cereais, legumes, algodão e mandioca. O investimento público foi substancial, pois, além de casas, o governo provincial providenciava a construção de dois açudes.

A inauguração da Colônia Christina ocorreu em 13 de junho de 1880, durante a administração do presidente de província, José Júlio de Albuquerque Barros. Naquele ano, havia 55 crianças asiladas e inúmeras outras à espera de recolhimento, instaladas provisoriamente no antigo abarracamento de Jacarecanga, erguido durante a seca e onde, segundo o relatório da presidência, já recebiam educação. Nesse abarracamento, existiam 135 menores de 12 anos abrigados em uma escola e 79 órfãos maiores de 12 anos recolhidos em casa contígua. Outros órfãos não conduzidos nem para a Colônia nem para o abarracamento estavam internados na Santa Casa de Misericórdia de Fortaleza.

A Colônia acolhia também filhas livres de mulheres escravas que estavam "a cargo do Estado", além de receber crianças cujos pais tinham condições de pagar e dar-lhes educação. O trabalho interno era dividido por sexos, e a educação também tinha tratamento diferenciado: os meninos recebiam ensino primário e secundário, enquanto às meninas era transmitida apenas educação primária (Souza, 1999, p.59).

Rodolfo Theófilo, em História da seca do Ceará (1877 a 1880), demonstrou preocupação acerca da longevidade da Colônia Christina, se, além dos recursos provinciais, não houvesse também financiamento por parte do governo geral: 
Receamos pela vida da colônia, porquanto auxiliada unicamente pelos recursos da província, não poderá ir muito longe. Não será em cinco anos, embora voltando estações regulares, que o Ceará se há de restabelecer, e, neste período, se o governo geral não auxiliar a colônia, ela tem de extinguir-se (Theófilo, 1922, p.358).

Apesar das ponderações feitas por Rodolfo Theófilo, convém destacar que, das três instituições assistenciais projetadas durante esse período, somente a Colônia Christina foi finalizada ainda sob o ambiente da seca, em 1880.

Outro motivo de grande preocupação por parte das elites e do governo provincial foi a questão do quantitativo de loucos em Fortaleza.

\section{Asilo de Alienados São Vicente de Paula}

Como prática anteriormente observada nas duas instituições assistenciais acima referidas, os discursos em torno da intenção da criação de um asilo para alienados foram novamente atribuídos pelos contemporâneos a uma única pessoa: Severiano da Cunha Freire, o visconde de Cauípe, irmão de Joaquim da Cunha Freire, o idealizador do Asilo de Mendicidade.

De forma semelhante às narrativas produzidas em torno dos personagens inspiradores das obras destinadas à mendicidade e orfandade, Severino da Cunha Freire tornou-se a grande referência na concepção do projeto de institucionalização da loucura, sobretudo quando, em 1874, doou dois contos e quinhentos mil réis para as obras do asilo de alienados quando ele exercia a função de vice-provedor da Santa Casa de Misericórdia de Fortaleza. Os membros da mesa administrativa do hospital receberam a doação com irrefutável entusiasmo, ao afirmar que a "oferta humanitária, era filha somente do coração bem formado do mesmo Sr. Vice Provedor" (Sessão..., 16 jul. 1874, p.26).

A doação de Severiano da Cunha Freire foi registrada em ata de reunião da Santa Casa, a partir de um discurso permeado por troca de gentilezas por parte dos membros da mesa administrativa do hospital e por aparente modéstia por parte do vice-provedor Severino da Cunha Freire. O discurso torna-se emblemático ao se observar o lugar da filantropia na sociedade provincial oitocentista. O mordomo da irmandade, o senhor Feijó, propôs que o presidente da província tomasse conhecimento da generosa doação. Proposta que foi considerada desnecessária por Severiano da Cunha Freire, mas que fora imediatamente rebatida pelo mordomo como relevante para se fazer justiça à sua elevada atitude. Após trocas de discursos lisonjeiros entre os membros da mesa administrativa da Santa Casa, seguiram-se outras doações realizadas pelos demais mordomos, como milheiros de tijolos de alvenaria e outras quantias em dinheiro, mas todas foram inferiores à ofertada pelo vice-provedor.

Em relatório de 1875, o então presidente da província Heráclito Graça referiu-se a Severino da Cunha Freire como o grande idealizador da obra asilar: O "ilustre Visconde de Cauípe... concebeu o generoso pensamento de fundar um asilo de alienados e deveria ser merecedor das bênçãos da posteridade por sua inspiração humanitária" (Relatório..., 1 mar. 1875, p.17). As "bênçãos da posteridade" de fato ocorreram quando, em 1896, o historiador Guilherme Studart prestou-lhe larga homenagem, por meio de narrativa permeada por lisonjas e referência biográfica. 
Pessoa de grande projeção social entre a elite provincial, o visconde de Cauípe exerceu vários cargos políticos. Foi tenente-coronel comandante do segundo Batalhão da Guarda Nacional, vice-cônsul da Áustria e presidente da Associação Comercial da Praça do Ceará. Entretanto, foi na condição de vice-provedor da Santa Casa de Misericórdia que ele manifestou sua intenção de construir edifício para o recolhimento dos loucos. Guilherme Studart, ao exaltar seus valores morais, nomeou a idealização desse e de outros projetos caritativos seus produtos de um indivíduo "predestinado ... a semear o bem ... por toda a parte".

O Asilo de S. Vicente de Paula é produto de sua criação, e a sua iniciativa veio do fato de ter contemplado, errante e perseguida, andrajosa e faminta, uma pobre louca nas ruas desta cidade...

A Santa Casa de Misericórdia deve-lhe muito e muito, e pode-se dizer, sem hipérbole, que ao seu impulso fecundo elevou-se a altura em que ora a vemos como um completo monumento de caridade (Studart, 1896, p.229).

Ainda na perspectiva de analisarmos os discursos que homenagearam membros da elite provincial, reconhecidos publicamente por suas ações na construção de instituições assistenciais e de doações filantrópicas, o literato Antônio Sales (1995, p.34), na obra Novos retratos e lembranças, fez menção aos irmãos Cunha Freire - Joaquim e Severiano destacando seus feitos, enfatizando suas qualidades, mas apontando algumas diferenças. Enquanto Joaquim (referenciado como o grande responsável pelo asilo de mendicidade) recebeu o título de barão pelo Imperador, Severiano fora condecorado a visconde pelo rei de Portugal. Em termos de personalidade, enquanto Joaquim era descrito como homem "não culto" e nem "sempre generoso", Severiano era considerado mais "instruído, de gostos apurados, filantropo".

Discursos de teor filantrópico foram marcas presentes entre os membros das elites cearenses, mas eles estiveram longe de representar fato isolado ou local e constituíramse como prática comum em outras realidades brasileiras quando o assunto era oferecer assistência aos pobres, tanto no período monárquico como no republicano (Viscardi, 2011; Sanglard, Ferreira, 2014; Pinto, 2017; Coe, 2013; Moraes, Tavares, Souza, 2017; Santana, 2017). No Ceará, o sentido da filantropia para as elites estava intimamente articulado à ideia de recompensa social, ou seja, não bastava praticar doações, era necessário visibilizá-las, torná-las públicas, e, para isso, as elites utilizavam-se de distintos veículos de divulgação, fosse por meio de jornais, fosse por meio de órgãos oficiais, sob o argumento de que suas ações deveriam servir de incentivo para novas doações e outras obras filantrópicas. É nessa perspectiva que se inserem os três "idealizadores" das instituições asilares: Luiz Ribeiro da Cunha e os irmãos Cunha Freire. Eles mesclavam suas ações, aparentemente altruístas, mas de forte projeção social, com práticas públicas direcionadas à problemática da assistência aos pobres da província.

No que se refere especificamente ao asilo de alienados, o visconde de Cauípe não teve a oportunidade de ver "sua" obra concretizada, posto que faleceu em 1876. Antes disso, em 1875, o presidente da província Heráclito Graça enfatizava que a situação dos loucos era pior que a dos demais doentes, pois se encontravam "mais dignos de lástima e por isso também precisão de trato e cura, como os outros" (Relatório..., 1 mar. 1875, p.17). 
Uma questão importante a se destacar é que, apesar de as três instituições fazerem parte do mesmo cenário assistencial do início dos anos 1880, ao contrário das duas obras voltadas para a mendicância e orfandade, o asilo de alienados foi proposto antes mesmo do advento da seca.

Data de 1871 um dos primeiros documentos em que a loucura foi tratada como problema a ser enfrentado pelo governo. No relatório da presidência de província, o vice-provedor interino da Santa Casa, Victoriano Augusto Borges, considerava "urgente" a construção de um abrigo para os loucos que se encontravam expostos pelas ruas da capital, pois eles incomodavam os transeuntes e ofendiam a moral e os bons costumes. Os valores utilizados para justificar a obra fundamentavam-se nos princípios da civilização e caridade:

Ainda há uma obra que reputo urgente, reclamada pela civilização, e pela sublime virtude - a caridade - é um lugar onde possam ser recolhidos os loucos, que muitas vezes, com ofensa dos bons costumes, da moral e atestando a nossa falta de cristianismo, vagueiam pelas ruas desta cidade (Relatório..., 4 jul. 1871, p.4).

Em ata de reunião, a mesa administrativa da Santa Casa registrou doações efetuadas por diferentes cidadãos da província em benefício do edifício. Em julho de 1874, o mordomo senhor Albano lançou a proposta de serem dirigidas cartas aos estrangeiros que possuíam casas ou relações comerciais no Ceará para que, de forma semelhante, fossem realizadas novas doações. Além disso, foi proposta a nomeação de uma comissão formada por médicos residentes da Santa Casa para angariar donativos entre os quais estava presente o doutor Meton de Alencar, o futuro primeiro médico do Asilo de Alienados São Vicente de Paula.

Eram variados os tipos de doadores e donativos destinados à instituição assistencial. Os doadores poderiam ser pessoas ou estabelecimentos, de Fortaleza ou de outras cidades do Ceará. Assim, a Santa Casa nomeou várias comissões nas localidades de Aracati, Maranguape, Mecejana, Sobral, Pereira, Acaracu; mas também buscou ajuda em outras províncias, como Pernambuco, onde o responsável pela arrecadação encontrou dificuldades de angariar donativos, haja vista que aquela província também empregava esforços para "construir um igual estabelecimento" (Sessão..., 17 set. 1874, p.31).

As doações também se davam de formas diferenciadas. Além dos donativos em dinheiro, havia a oferta de objetos de construção e a promoção de eventos artísticos, como a realização de concertos musicais. Em um deles, o senhor Joaquim Mendes da Rocha cedeu sua casa para ensaio a algumas senhoras da província em benefício do asilo de alienados. Artistas como Vicente Guilherme de Azevedo também ofereceram a venda de suas músicas e dividiram parte do lucro com o asilo. Foi realizado ainda um leilão na Santa Casa de Misericórdia contabilizando a "quantia superior a dez contos de réis" (Relatório..., 1 mar. 1875, p.17). Durante a administração de Heráclito Pereira Graça, o professor primário da vila de Pedra Branca, Joaquim Antônio da Silva Chaves, doou a quantia de $30 \$ 000$ réis.

Havendo o professor primário da vila de Pedra Branca, Joaquim Antonio da Silva Chaves, oferecido à esta presidência, no caráter de membro da Comissão encarregada de agenciar donativos para o asilo de alienados, nesta Capital, a quantia de $30 \$ 000$ reis; sirva-se Vmce de comunicar ao respectivo coletor, a fim de que se torne efetivo o desconto da aludida quantia (Ofícios, $11 \mathrm{dez} .1874$, p.61). 
Em 1875, uma peça dramatúrgica de composição - cuja autoria não foi mencionada -, a ser apresentada no Teatro São José em Fortaleza, também teve a mesma finalidade, assim como percentuais de exposição de produtos agrícolas, de bazares e até recursos oriundos de testamentos escritos por um tenente-coronel de Boa Viagem foram destinados ao asilo de alienados. Mais donativos, resultado da venda de objetos de um bazar, foram contabilizados na quantia de 28:000\$000. Todas as doações foram devidamente registradas e celebradas pela mesa regedora da Santa Casa e por relatórios públicos.

Antes, porém, do recebimento das doações, havia uma questão em aberto: a localização em que seria erguido o asilo de alienados. A intenção inicial da mesa administrativa era de o estabelecimento situar-se nas proximidades da Santa Casa, voltado para a rua Amélia, ou mesmo de incorporá-lo em suas dependências. Em julho de 1874, porém, o médico João Moreira da Rocha ponderava ser inconveniente a ideia de edificação de um asilo em frente à Santa Casa, não apenas pela proximidade que teriam os loucos com os demais doentes do hospital, mas pela insuficiência de espaço e acomodações para atender à demanda. Outro argumento utilizado pelo médico referia-se à medicina especializada em loucura, a qual defendia ser necessária a construção de "jardim para recreio dos alienados" (Sessão..., 30 jul. 1874, p.29) nos hospícios contemporâneos.

Em anexo do relatório de 1875, o visconde de Cauípe mais uma vez justificava a relevância da obra ao considerá-la uma das mais "palpitantes necessidades da província". $\mathrm{Na}$ tentativa de solucionar provisoriamente o local de abrigo para os doentes mentais, a mesa administrativa da Santa Casa anunciava ter levantado uma casa onde os "infelizes poderão encontrar, se não o completo reestabelecimento de suas faculdades, ao menos tratamento regular, condigno com seu estado" (Relatório..., 2 jul. 1875, p.3). Era o que poderia ser feito naquele momento, haja vista ser insuficiente o capital para a construção de estabelecimento próprio, apesar da "caridade e filantropia" não somente dos cearenses, mas de indivíduos de outras províncias que ofertaram donativos em objetos e dinheiro.

Em julho de 1877, quando a seca já se propagava pela província, o capitão Manoel Francisco da Silva Albano e sua esposa, dona Maria Theófilo Albano, fizeram a doação de um terreno na "estrada empreitada de Arronches", no valor de 1:000\$000 réis (Oliveira, 2011, p.86). A Santa Casa de Misericórdia organizou uma comissão para avaliar o novo local e concluiu encontrar-se nas "melhores condições", pois, além de estar próximo à lagoa de Porangaba, a "extensão superficial do terreno permite ao edifício projetado o maior desenvolvimento" (Escriptura..., 1874).

Segundo a escritura lavrada em cartório, o terreno - que fazia parte do sítio dos doadores - estava bem localizado, ocupava uma área próxima à "margem da estrada empedrada, do lado do poente, com fundos correspondentes até a lagoa da Porangaba" (Escritura..., 1874). Nesse terreno, seria erguido o Asilo de Alienados São Vicente de Paula. No momento em que a doação do terreno foi lavrada em cartório, as obras já estavam em construção adiantada, como consta no documento da escritura.

Em 7 de setembro de 1877, foi realizado oficialmente o lançamento da pedra fundamental do asilo para alienados.

A historiografia registrou o fato em duas publicações. A primeira, por meio da revista do Instituto do Ceará em matéria publicada em 1900, quando o historiador João Brígido (1900, 
p.216) referiu-se ao lançamento da pedra fundamental como resultado de duas iniciativas: a do "filatropo" visconde de Cauípe e a do "benemérito" coronel Manuel F. Albano, que doou o terreno para edificação da obra. O segundo registro encontra-se na obra Datas $e$ fatos para a história do Ceará, do barão de Studart, em que novamente o autor referiu-se ao asilo de alienados como uma iniciativa do visconde do Cauípe e das deliberações da Santa Casa de Misericórdia de Fortaleza (Studart, 1896, p.234).

O jornal oposicionista $O$ Retirante noticiou que: se a loucura era tratada com indiferença pelo governo, a caridade, entretanto, acolhia as "lágrimas da indigência" e a "loucura vai encontrar asilo". Segundo o jornal: "O dia de hoje é e será sempre um dia solene para este povo que sofre, para esta província que espera seu grande futuro" (O Retirante, 9 set. 1877, p.1). O visconde de Cauípe foi mais uma vez lembrado e homenageado tanto pela importância que o asilo possuía à época como pela gratidão que a "geração futura" sentiria pelo filantropo. Para o jornal: se "passam curtos os dias de uma existência", contudo, "perdura a memória dos benfeitores da humanidade" (p.1).

Por meio da análise dos enunciados discursivos de $O$ Retirante, observa-se que o lugar ocupado pela loucura na sociedade fortalezense girava em torno das noções de visibilidade e invisibilidade. Isso se torna perceptível no conteúdo da matéria publicada em homenagem ao visconde de Cauípe quando foi mencionado o momento em que ele havia idealizado o projeto. Ou seja, no início da década de 1870, a situação econômica da província era favorável à construção de um asilo para alienados, entretanto a obra não era prioritária para as autoridades públicas, embora houvesse demanda. Dessa forma, a iniciativa de Cauípe ganhava dimensão humanitária ainda maior, posto que denotava sentimento de sensibilidade em relação à questão da loucura em uma época em que a filantropia particular e instituições públicas mostravam-se indiferentes a ela.

$\mathrm{Na}$ época de abastança em que ele [visconde do Cauípe] estudou a chaga de nossa sociedade que precisava de mais urgente amparo - a loucura - desprotegida pelo escárnio de uns, pelo susto de outros, pela indiferença de muitos, sem dúvida deverá impressionar mais o seu espírito (O Retirante, 9 set. 1877, p.1).

Apesar de todo o lisonjeio nos agradecimentos direcionados ao visconde do Cauípe e expostos em vários discursos aqui investigados, cabe registrar um episódio bastante curioso e não fixado pelos memorialistas ou historiadores.

Trata-se de uma pendência financeira em que os mordomos da Santa Casa se depararam em 1878, quando foi descoberta uma dívida no valor de 2:019\$000 réis deixada pelo finado visconde do Cauípe referente à extração de bilhetes de loteria em benefício do asilo de alienados. A dívida foi pauta de discussão em várias reuniões da mesa administrativa, que procurou, mais de uma vez, a família de Severino da Cunha Freire para fazer-lhe a cobrança da quantia; esta, por sua vez, contestava-a, recusando-se a pagá-la. Diante do impasse, foi necessária a nomeação de um procurador sem, contudo, conseguir êxito na devolução do dinheiro. A despeito da recorrência do tema e das contestações em reuniões, a dívida aparentemente não ganhou visibilidade pelos jornais e tornou-se problema de ordem interna da mesa administrativa da Santa Casa. O tema da dívida foi encerrado, e, após o lançamento da pedra fundamental do Asilo de Alienados São Vicente de Paula, as obras foram impulsionadas. 
Em ofício emitido pela Santa Casa em 30 de setembro de 1878, o mordomo Silva Albano - após realizar balanço quanto às receitas e despesas do ano anterior - relatou estar a obra "em estado de grande adiantamento", destacou suas "melhores condições higiênicas", onde o "pavimento do edifício é elevado", e ressaltou que a "fachada principal se acha quase concluída". Contudo, ponderou sobre o pouco adiantamento em relação a alguns trabalhos, como o "serviço de capinagem". Sobre a questão financeira, ressaltou ainda que muito dinheiro fora empregado na obra: "cerca de trinta contos" (Correspondência, 1878, p.18).

A empolgação do relator era perceptível em vários momentos, sobretudo por destacar possuir o terreno excelente poço, que deveria "resistir às mais prolongadas secas", e por ele defender o sentido humanitário da obra, ao afirmar:

Toda a dificuldade me parece será no começo e estou convencido de que assim como em outras províncias, o Ceará há de também por sua vez poder colaborar uma grande obra humanitária, tornando a si o caridoso encargo de tratar dos que mais sofrem (Correspondência, 30 set. 1878, p.18).

E finaliza Silva Albano, ao emitir sua gratidão aos poderes públicos e à filantropia particular e ao reafirmar o "amplo e generoso concurso com que se entrou para a obra", referindo-se a esses dois segmentos sociais.

\section{As três instituições assistenciais: financiamentos e mão de obra}

Em termos de financiamento, as três instituições assistenciais receberam recursos, sobretudo das loterias extraídas pelo governo provincial e das doações individuais e coletivas.

Sobre as loterias, foram concedidas duas em agosto de 1800 , no valor total de trinta contos de réis em favor da Colônia Cristina. Antes disso, em 1875, já haviam sido destinadas loterias ao asilo de alienados. Em setembro de 1876, quatro, no valor de trinta contos de réis cada uma e divididas em três mil bilhetes, foram cedidas em benefício do asilo de alienados.

Sobre as doações, em 1878, o asilo de mendicidade recebeu a quantia de 1:000\$000 réis como produto de concerto musical realizado em Recife e promovido pelo doutor José Bernardo Galvão Alcoforado por intermédio do barão de Ibiapaba. No mesmo ano, o governo provincial conseguiu arrecadar a quantia de 15:000,000 réis em doação. Foram nomeadas, ainda pelo governo, comissões de doação para angariar fundos em várias localidades da província em benefício da Colônia Cristina.

Apesar desses recursos, a construção das três instituições somente se tornou viável pela abundância de mão de obra barata ou mesmo gratuita proveniente dos retirantes da seca mulheres, homens e crianças trabalhadores e, potencialmente, futuros moradores dos asilos.

No caso do asilo para alienados, "considerável população de indigente no povoado" (Fala..., 1 nov. 1878, p.35) de Arronches foi a grande responsável pela construção do edifício. O discurso do então presidente da província, José Júlio Aguiar, apresentado em relatório oficial, afirmava que a utilização da mão de obra indigente era necessária para "conservarlhe os hábitos do trabalho" e evitar o costume de pedir esmolas (p.35). 
Em relatório de 30 de setembro de 1878 ao presidente da província, a Santa Casa destacava a estratégia em utilizar a força de trabalho indigente no povoado de Arronches como forma de evitar que parte da população do interior se fixasse em Fortaleza:

A conveniência de fixar na povoação de Arros [Arronches] uma certa parte da população do interior, que para a capital se dirigia em demanda de recursos, facilitou a prestação do auxílio em pessoas para a obra...

Pode-se calcular por trinta e dois mil e quinhentos operários, termo médio, o pessoal fornecido a obra, desde o seu começo a 28 de Agosto do ano passado (Correspondência, 30 set. 1878, p.18).

A partir de semelhantes condições, outros trabalhadores, mulheres e homens indigentes, foram empregados em diversas obras públicas. Em finais da seca, segundo o presidente da província José Júlio Aguiar, foram registradas cerca de quinhentas obras públicas concluídas em toda a província, dentre as quais destacaram-se: "73 açudes, 64 igrejas, 50 cemitérios, 60 estradas e ladeiras, 48 cadeias, 31 poços de alvenaria, 29 escolas; 19 pontes, 23 calçamentos de estradas e ruas, 27 aterros (viadutos etc.), 14 mercados, 7 canos de esgotos, 3 quartéis, 3 asilos e 30 obras diversas" (Fala..., 1 jul. 1880, p.44).

\section{Considerações finais}

As três instituições - Asilo de Mendicidade, Colônia Orfanológica Cristina e Asilo de Alienados São Vicente de Paula - atenderam às semelhantes propostas de oferecer assistência pública, em nome da filantropia privada, aos segmentos específicos de pobres: mendigos, órfãos e loucos. Houve várias similitudes entre as instituições. Em primeiro lugar, suas edificações estiveram marcadamente vinculadas ao traço personalista de seus idealizadores: Joaquim da Cunha, Luiz Ribeiro da Cunha e Severino da Cunha Freire, respectivamente. Todos eles pertenciam às elites econômicas, possuíam grande prestígio social e político, foram condecorados com títulos e honrarias - à semelhança do que ocorria na Corte (Schwarcz, 1998) - por seus feitos filantrópicos e foram imortalizados por discursos memorialistas e historiográficos cearenses.

Em segundo lugar, as três instituições estavam localizadas em espaços distantes dos centros de poder de Fortaleza, o que evitava assim o convívio das elites com pessoas indesejáveis socialmente. No caso dos asilos de alienados e mendicidade, ambos se situavam próximos às estações da via férrea de Baturité que interligavam Fortaleza a várias localidades interioranas.

Outro elemento importante para a análise das instituições assistenciais foi o fato de elas estarem unidas sob a forte preocupação por parte das elites com o significativo aumento da pobreza - questão solidamente discutida pelas historiografias brasileira e portuguesa (Sanglard, Lopes, 2018) e terem sido planejadas em virtude do atordoado caos social decorrente da seca de 1877-1879. Especificamente no que concerne aos dois asilos - de mendigos e alienados -, tornava-se difícil distinguir os indivíduos que estavam situados entre as condições de mendicância e insanidade, posto que muitos estavam inseridos no mesmo universo desolador de miséria e desespero. Ao analisar a fala do presidente 
da província - José Júlio de Albuquerque Barros, em relatório pronunciado à assembleia provincial, quando afirmou que "a população faminta, seminua e desvairada, precipitavase do centro para o litoral, como uma torrente, alastrando de cadáveres as estradas (Fala..., 1 nov. 1878, p.39) -, torna-se oportuno indagar: o que ou quem poderia ser considerado normal ou insano naqueles difíceis anos, sobretudo quando os retirantes, motivados pela fome, submetiam-se a práticas de "antropofagia", como ocorreu no município de Lavras, noticiadas pelos próprios documentos oficiais?

$\mathrm{Na}$ análise dos discursos dos testemunhos da época, é possível observar a relação intrínseca estabelecida entre a seca e a miséria: "É difícil encontrar-se uma cidade mais infestada de pedintes do que Fortaleza. A razão desta estupenda mendicidade está nas secas" (Theófilo, 1997, p.116). Daí as elites avaliarem ser urgente a construção de espaços assistenciais à pobreza com o intuito de barrar seu avanço no coração da capital. O medo e a desconfiança de determinados segmentos econômicos e políticos de Fortaleza em relação ao crescimento diversificado de pedintes e marginalizados eram motivos suficientes para que tais empreendimentos fossem rapidamente viabilizados, com a justificativa de preservação dos bons costumes e da moral, além do restauro do controle social.

A seca desencadeou nova configuração econômica e social quanto à questão da marginalização em Fortaleza, uma vez que ela acentuou uma realidade já existente, embora até então controlável. A circunstância nova era que as elites demonstravam seu constrangimento e sua insatisfação diante do espetáculo que presenciavam e "que deprimia esta capital, de esmoleres pelas ruas" (Souza, 1999, p.136).

Contudo, com o fim da seca, gradativamente, a situação dos pobres retomava seu antigo lugar. A loucura retornou à sua condição de não prioridade, quando a intensidade das obras de construção do asilo de alienados começou a se fazer diminuta. No que se refere à mendicidade, também houve descontinuidade em lhe oferecer tratamento emergencial, haja vista que o prédio concluído não atendeu ao propósito inicial e tornou-se, posteriormente, local para a edificação do Colégio Militar de Fortaleza. Das três obras assistenciais do período, somente a Colônia Cristina fora inaugurada um ano após o término oficial da seca, em 1880, em uma demonstração de que a infância delinquente representava prioridade para as autoridades no que se refere à prevenção e ao combate da criminalidade juvenil e ao disciplinamento da pobreza.

Convém observar ainda que o sentido da filantropia se configurava como elemento crucial para a compreensão do processo de institucionalização da assistência à pobreza no Ceará oitocentista. Ele permeou todos os discursos e deu o tom sobre a urgência em sua viabilização como utilidade social cujo objetivo central era resolver problemas da sociedade. O discurso da filantropia reforçou a necessidade das obras, construiu a imagem personalizada dos "homens de bem" - aparentemente destituídos de interesses particulares -, e mais, atenuava as obrigações por parte dos governos provincial e central frente à realização de ações públicas voltadas para a assistência. O discurso da filantropia, por fim, construiu uma memória valorativa e mitificada em que grandes personagens das elites - a maioria homens, mas também mulheres - tornaram-se pessoas imprescindíveis na condução das ações da cidade e ditaram os destinos daqueles destituídos socialmente. A generosidade de suas doações, contudo, muitas vezes fora motivada por razões outras que não necessariamente 
as ditas humanitárias, apesar de os enunciados discursivos evocarem tais princípios. O interesse das elites em erguer locais de acolhimento à pobreza ia ao encontro do processo de higienização e sanitarismo urbano vivenciado por Fortaleza.

Além desse fator, exercer a filantropia atendia às expectativas de novo discurso constituído pelo ideário burguês moderno no que tange à temática da escravidão. Joaquim da Cunha, Luiz Ribeiro da Cunha e Severino da Cunha Freire, durante as décadas de 1860 e 1870, enriqueceram e conquistaram cargos políticos por meio da comercialização de negros e negras escravizados. Eles eram conhecidos - e respeitados - traficantes de escravos e possuíam, juntamente com outros negociantes do setor, escritórios na charmosa rua Amélia, em Fortaleza (Rodrigues, 2018, p.57). Entretanto, a partir da década de 1870, eles alteraram seus discursos e práticas escravocratas e posicionaram-se, entusiasticamente, como abolicionistas: "alforriavam homens e mulheres em saraus abolicionistas e doavam recursos para obras de filantropia" (p.81). Assim, o exercício da filantropia levava-os a outro lugar de prestígio social por meio de processos e mudanças institucionais, tanto na dimensão política como socioeconômica a partir do ambiente de crises vivenciado pela monarquia brasileira no que tange às relações no mundo do trabalho.

É necessário, por fim, ressaltar que as novas práticas burguesas e os ideários civilizatórios e filantrópicos apregoados pelas elites não corresponderam aos interesses, demandas e anseios de uma massa heterogênea de populares, composta por livres, libertos, escravos, negros, indígenas, caboclos, ou seja, pertencente a distintos grupos sociais relegados, tradicionalmente, à marginalização e à exclusão. O que se evidenciou no Ceará oitocentista foi a constituição de um traço personalista intrinsicamente atrelado às instituições assistenciais pela construção de discursos e práticas em que se notabilizaram doadores e suas doações, reforçando suas projeções sociais e políticas e delineando um projeto institucional segregador para a pobreza desvalida, louca e perigosa desempenhado por parte das elites.

\section{REFERÊNCIAS}

ARANTES, Adlene Silva.

O papel da Colônia Orfanológica Isabel na educação e na definição dos destinos de meninos negros, brancos e índios na Província de Pernambuco (18741889). Dissertação (Mestrado em Educação) - Universidade Federal de Pernambuco, Recife. 2005.

\section{BRASIL.}

Decreto n.9.853, de 3 de fevereiro de 1888 . Concede permissão ao Barão de Ibiapaba para explorar minas de cobre no municipio do Ipú, da Província do Ceará. Portal Senado. 1888.

BRÍGIDO, João.

Efemérides do Ceará. Revista Trimestral do Instituto do Ceará, ano 14, p.137-226. 1900.

CHAVES, José Olivenor S.

Fortaleza e os retirantes da seca de 1877-1879: o real de um imaginário dominante. 1995. Dissertação (Mestrado em História) - Universidade Federal de Pernambuco, Recife. 1995.
COE, Agostinho Júnior Holanda.

A assistência em crise: a Santa Casa da

Misericórdia do Maranhão na segunda metade do século XIX (1850-1890). Tese (Doutorado em História das Ciências e da Saúde) - Fundação Oswaldo Cruz, Rio de Janeiro. 2013.

CORRESPONDÊNCIA.

Livro de Correspondência Oficial, n.2. (Arquivo Público do Ceará, Fortaleza). 30 set. 1878.

ESCRITURA...

Escritura de doação que fazem o capitão Manoel Francisco da Silva Albano e sua mulher à Santa Casa de Misericórdia desta cidade, de um terreno na estrada Empreitada de Arronches, para o edifício do Asilo de Alienados, por 1:000\$000. (Acervo do Hospital São Vicente de Paulo, Fortaleza). 1874.

FALA...

Fala do presidente da província, José Júlio de Albuquerque Barros à Assembleia Provincial. 
(Acervo do Hospital São Vicente de Paulo, Fortaleza). 1 jul. 1880.

FALA...

Fala do presidente da província, José Júlio de Albuquerque Barros, à Assembleia Provincial. (Acervo do Hospital São Vicente de Paulo, Fortaleza). 1 nov. 1878.

LIMA, Francisco de Assis Silva de; PEREIRA, José Hamilton.

Estradas de ferro no Ceará. Fortaleza: Expressão. 2007.

MORAES, Cristina; TAVARES, Lara; SOUZA, Rildo.

Três tempos de caridade, assistência e filantropia em Goiás. Questões e Debates, v.65, n.1, p.5-16. 2017.

NEVES, Frederico Castro.

A multidão e a história: saques e outras ações de massas no Ceará. Rio de Janeiro: Relume Dumará. 2000.

OFÍCIOS.

Ofícios: Tesouraria Provincial e Coletorias (187476), n.159, p.61 (Arquivo Público do Ceará, Fortaleza). 11 dez. 1874.

OLIVEIRA, Cláudia Freitas de.

O Asilo de Alienados São Vicente de Paula e a institucionalização da loucura no Ceará (18711920). Tese (Doutorado) - Universidade Federal de Pernambuco, Recife. 2011.

O RETIRANTE.

O Retirante, p.1. 9 set. 1877.

O RETIRANTE.

O Retirante, Um pouco de tudo, p.4. 15 jun. 1877.

PINTO, Ana Paula Magno

Assistência, saúde e sociedade: a Sociedade São

Vicente de Paulo na Zona da Mata mineira (1895-1939). Tese (Doutorado em História das Ciências e da Saúde) - Fundação Oswaldo Cruz, Rio de Janeiro. 2017.

\section{RELATÓRIO...}

Relatório do presidente da Província, Esmerino Gomes Parente de 2 de julho de 1875. Anexo n.11. (Arquivo Público do Ceará, Fortaleza). 2 jul. 1875 .

\section{RELATÓRIO...}

Relatório do presidente da província, Heraclito d'Alencastro Pereira da Graça de 1 de março de 1875. item: SCM, p.17. (Arquivo Público do Ceará, Fortaleza). 1 mar. 1875.

RELATÓRIO...

Relatório do presidente da província, Barão de Taquari à Assembleia Provincial do Ceará de 4 jul. 1871. Anexo 8: Relatório do vice-provedor interino da SCM, Victoriano Augusto Borges, p.4. (Arquivo Público do Ceará, Fortaleza). 4 jul. 1871.

RODRIGUES, Eylo Fagner Silva.

Os párias da modernidade na "terra da luz": "a gente ínfima" de Fortaleza no processo de regulação da mão de obra urbana (1877-1912). Tese (Doutorado em História) - Universidade Federal do Ceará, Fortaleza. 2018.

SALES, Antônio.

Novos retratos e lembranças. Fortaleza: UFC; Casa José de Alencar. 1995.

SANGLARD, Gisele; FERREIRA, Luiz Otávio. Pobreza e filantropia: Fernandes Figueira e a assistência à infância no Rio de Janeiro (19001920). Estudos Históricos, v.27, n.53, p.71-91. 2014.

SANGLARD, Gisele; LOPES, Maria Antônia. Pobreza e assistência: debates historiográficos. Tempo, v.24, n.2, p.280-284. 2018.

SANTANA, Márcia Castelo Branco.

Asilo de Alienados de Teresina: história da assistência e da institucionalização dos loucos[as] no Piauí (1880 a 1920). Tese (Doutorado em História) - Universidade Federal de Pernambuco, Recife. 2017.

SCHWARCZ, Lilia Moriz.

As barbas do imperador: D. Pedro II, um monarca nos trópicos. São Paulo: Companhia das Letras. 1998.

SESSÃO...

Sessão de 17 de setembro de 1874. Livro de Atas de 19 de março de 1873. (Acervo da Santa Casa de Misericórdia, Fortaleza). 17 set. 1874.

SESSÃO...

Sessão de 30 de julho de 1874. Livro de Atas de 19 de março de 1873. (Acervo da Santa Casa de Misericórdia, Fortaleza). 30 jul. 1874.

SESSÃO...

Sessão de 16 de julho de 1874. Livro de Atas de 19 de março de 1873. (Acervo da Santa Casa de Misericórdia, Fortaleza). 16 jul. 1874.

SILVA, Marcos José Diniz.

Moderno-espiritualismo e espaço público republicano: maçons, espíritas e teosofistas no Ceará. Tese (Doutorado em Sociologia) Universidade Federal do Ceará, Fortaleza. 2009.

SOUZA, Josinete Lopes de.

Da infância "desvalida" à infância "delinquente": Fortaleza (1865-1928). Dissertação (Mestrado em História Social) - Pontifícia Universidade Católica de São Paulo, São Paulo. 1999.

STUDART, Guilherme.

Estrangeiros e Ceará. Revista do Instituto do Ceará, n.36. 1922. 
STUDART, Guilherme.

Datas e fatos para a história do Ceará. v.2.

Fortaleza: Tipografia Studart. 1896.

THEÓFILO, Rodolfo.

Varíola e vacinação no Ceará. (Edição fac-símile). Fortaleza: Fundação Waldemar Alcântara. 1997.

THEÓFILO, Rodolfo.

História da seca do Ceará (1877 a 1880). Rio de Janeiro: Imprensa Inglesa. 1922.
VASCONCELLOS, Rodolfo Smith de; VASCONCELLOS, José Smith de (Org.). Arquivo nobiliárquico brasileiro. Lausanne: La Concorde. 1918.

VISCARDI, Cláudia Maria Ribeiro. Pobreza e assistência no Rio de Janeiro na Primeira República. História, Ciências, SaúdeManguinhos, v.18, supl.1, p.179-197. 2011. 